\title{
Soil Application of Tannery Land Plaster: Effects on Nitrogen Mineralization and Soil Biochemical Properties
}

\author{
Caterina Giacometti, Luciano Cavani, Paola Gioacchini, \\ Claudio Ciavatta, and Claudio Marzadori
}

\author{
Department of Agro-Environmental Sciences and Technologies, Alma Mater Studiorum University of Bologna, \\ Viale Fanin 40, 40127 Bologna, Italy \\ Correspondence should be addressed to Caterina Giacometti, caterina.giacometti2@unibo.it \\ Received 6 May 2011; Revised 8 July 2011; Accepted 11 July 2011 \\ Academic Editor: Giuseppe Corti
}

Copyright ( $\odot 2012$ Caterina Giacometti et al. This is an open access article distributed under the Creative Commons Attribution License, which permits unrestricted use, distribution, and reproduction in any medium, provided the original work is properly cited.

Tannery land plaster (TLP) is a byproduct of lime hydrolysis of leather shavings. Its use in agriculture (organic $\mathrm{C} \approx 17 \%$, $\mathrm{N} \approx 6 \% \mathrm{dm})$ could represent an alternative to landfill or incineration, but the high $\mathrm{Cr}(\mathrm{III})$ content $(\approx 5 \% \mathrm{dm})$ makes it necessary to evaluate the effect on soil biochemical properties. TLP was therefore added at the rates of 220 and $440 \mathrm{~kg}^{\circ} \mathrm{N}$ ha ${ }^{-1}$ to 2 agricultural soils and incubated for 56 days under controlled conditions. Extractable $\mathrm{NH}_{4}{ }^{+}-\mathrm{N}_{\text {and }} \mathrm{NO}_{3}{ }^{-}-\mathrm{N}, \mathrm{CO}_{2}-\mathrm{C}$ evolution, microbial biomass-N, protease activity, and extractable $\mathrm{Cr}$ were monitored. The organic $\mathrm{N}$ was readily mineralized $(>50 \%$ in the first week) and a significant increase in microbial activity was measured, regardless of soil type and addition rate. Extractable $\mathrm{Cr}$ (III) quickly decreased during the incubation. The absence of a negative impact on soil biochemical properties seems to support the use of TLP in agriculture, although further investigations in long-term field experiments are suggested.

\section{Introduction}

The production of biosolids from municipal solid waste, sewage sludge, and waste of agroindustrial origin is continually increasing [1]. Their potential use in agriculture as an alternative method to landfill or incineration has become an increasingly attractive option, due to current trends in European waste policy [2,3]. The agricultural use of these byproducts could help in maintaining soil organic matter $(\mathrm{OM})$ content and promoting the recycling of plant nutrients, thus reducing the use of chemical fertilizers [1] and increasing agricultural production sustainability [4]. However, in order to recycle biosolids in soil it is necessary to exclude any hazardous effects for humans, animals, plants, and soil microbial populations. Appropriate control of chemical and physical characteristics of the biosolids, nutrients, and heavy metal dynamics in soils is needed in order to guarantee the agronomical value of the products and environmental safety.
Tannery land plaster (TLP) is a by-product of lime hydrolysis of leather shavings, a residue of the leather production cycle classified as treated industrial sewage sludge [5]. After the alkaline hydrolysis of leather shavings, sulphuric acid is added to neutralize the suspension, and a calcium sulphate precipitate is then separated by filtration, obtaining the TLP. TLP is currently disposed of in landfill or, at best, used to correct soil acidity. However, due to the significant amount of $\mathrm{N}(\approx 6 \% \mathrm{dm})$ its soil application as a source of organic $\mathrm{N}$ may represent a more suitable recycling strategy.

TLP originates from $\mathrm{Cr}$ tanned animal hides, thus it contains large amounts of $\mathrm{Cr}(\mathrm{III})(\approx 5 \% \mathrm{dm})$, a human, and animal micronutrient but, at the same time, a potentially toxic element [6] that could represent a factor of concern in agriculture and the environment. To date European legislation on sewage sludge [5] does not set any threshold value for $\mathrm{Cr}$, even though the introduction of such a limit is presently under discussion (total $\mathrm{Cr}$ in sewage sludge and 
TABLE 1: Chemical characteristics of tannery land plaster (TLP).

\begin{tabular}{|c|c|c|}
\hline Parameter & Units & $\begin{array}{c}\text { Value (all data are } \\
\text { expressed on a dry } \\
\text { matter basis) }\end{array}$ \\
\hline Water content & $\left(\mathrm{g} \mathrm{kg}^{-1}\right)$ & $730^{*}$ \\
\hline Total solids (TS) & $\left(\mathrm{g} \mathrm{kg}^{-1}\right)$ & $270^{*}$ \\
\hline Ash & $\left(\mathrm{g} \mathrm{kg}^{-1}\right)$ & 660 \\
\hline Volatile solids (VS) & $\left(\mathrm{g} \mathrm{kg}^{-1}\right)$ & $90^{*}$ \\
\hline $\mathrm{pH}$ (in water) & $\mathrm{pH}$ & 10.6 \\
\hline Electrical conductivity (EC) & $\left(\mathrm{dS} \mathrm{m} \mathrm{m}^{-1}\right)$ & $3.6^{*}$ \\
\hline Total organic carbon (TOC) & $(\%)$ & 17 \\
\hline Total nitrogen (TN) & $\left(\mathrm{g} \mathrm{kg}^{-1}\right)$ & 57 \\
\hline $\mathrm{NH}_{4}^{+}-\mathrm{N}$ & $\left(\mathrm{g} \mathrm{kg}^{-1}\right)$ & 0.7 \\
\hline $\mathrm{NO}_{3}{ }^{-} \mathrm{N}$ & $\left(\mathrm{g} \mathrm{kg}^{-1}\right)$ & 0.3 \\
\hline $\mathrm{C}: \mathrm{N}$ ratio & - & 3 \\
\hline Total P & $\left(\mathrm{g} \mathrm{kg}^{-1}\right)$ & 3.1 \\
\hline Total K & $\left(\mathrm{g} \mathrm{kg}^{-1}\right)$ & 0.24 \\
\hline Total S & $\left(\mathrm{g} \mathrm{kg}^{-1}\right)$ & 123 \\
\hline Total Ca & $\left(\mathrm{g} \mathrm{kg}^{-1}\right)$ & 175 \\
\hline Total Mg & $\left(\mathrm{g} \mathrm{kg}^{-1}\right)$ & 3.9 \\
\hline Total $\mathrm{Na}$ & $\left(\mathrm{g} \mathrm{kg}^{-1}\right)$ & 2.3 \\
\hline Total Fe & $\left(\mathrm{mg} \mathrm{kg}^{-1}\right)$ & 755 \\
\hline Total Cu & $\left(\mathrm{mg} \mathrm{kg}^{-1}\right)$ & 3.3 \\
\hline Total Zn & $\left(\mathrm{mg} \mathrm{kg}^{-1}\right)$ & 8.3 \\
\hline Total Mn & $\left(\mathrm{mg} \mathrm{kg}^{-1}\right)$ & 36 \\
\hline Total Co & $\left(\mathrm{mg} \mathrm{kg}^{-1}\right)$ & 9.6 \\
\hline Total Al & $\left(\mathrm{mg} \mathrm{kg}^{-1}\right)$ & 373 \\
\hline Total Cd & $\left(\mathrm{mg} \mathrm{kg}^{-1}\right)$ & $<1.0$ \\
\hline Total Ni & $\left(\mathrm{mg} \mathrm{kg}^{-1}\right)$ & 1.6 \\
\hline Total $\mathrm{Pb}$ & $\left(\mathrm{mg} \mathrm{kg}^{-1}\right)$ & $<0.5$ \\
\hline Total Cr & $\left(\mathrm{g} \mathrm{kg}^{-1}\right)$ & 52.0 \\
\hline $\mathrm{Cr}(\mathrm{VI})$ & $\left(\mathrm{mg} \mathrm{kg}^{-1}\right)$ & $<0.5$ \\
\hline
\end{tabular}

*Fresh matter.

soil). However, since the form in sewage sludge is $\mathrm{Cr}(\mathrm{III})$, characterized by very low mobility and translocation in both soil and plants [7], we believe that its available fraction, rather than its total concentration, is the key parameter determining its potential toxicity. Although $\mathrm{Cr}(\mathrm{III})$ is 3 orders of magnitude less toxic than $\mathrm{Cr}(\mathrm{VI})$ [8], at high concentrations it can be harmful to the microbial community. Liang and Tabatabai [9] found an inhibitor effect on soil $\mathrm{N}$ mineralization processes after the addition of sewage sludge at a concentration of $\mathrm{Cr}(\mathrm{III})$ of $550 \mathrm{mg} \mathrm{kg}^{-1}$. Soil biological parameters can be used as effective indicators of modification in soil status due to pollution and variation in soil management [9]. Soil respiration, a good indicator of the oxidation of the soil $\mathrm{OM}$ to $\mathrm{CO}_{2}$ by aerobic heterotrophic microorganisms, and enzyme activities related to the cycle of main nutrients could give important indications on the rate of nutrient turnover. These parameters can also be used as a measure of microbial activity and its level of disturbance by inhibiting effects of pollutants and particularly of heavy metals $[10,11]$. Plant availability of organic $\mathrm{N}$ in a biosolid
TABle 2: Main physical and chemical characteristics of the two soils ( $\mathrm{M}$ and $\mathrm{P})$.

\begin{tabular}{lccc}
\hline \multirow{2}{*}{ Parameter } & \multirow{2}{*}{ Units } & \multicolumn{2}{c}{ Soil } \\
& & $\mathrm{M}$ & $\mathrm{P}$ \\
\hline Sand & $\left(\mathrm{g} \mathrm{kg}^{-1}\right)$ & 330 & 340 \\
Silt & $\left(\mathrm{g} \mathrm{kg}^{-1}\right)$ & 510 & 500 \\
Clay & $\left(\mathrm{g} \mathrm{kg}^{-1}\right)$ & 160 & 160 \\
Water holding capacity (WHC) & $\left(\mathrm{g} \mathrm{kg}^{-1}\right)$ & 310 & 280 \\
pH (in water) & - & 8.3 & 7.9 \\
Total calcium carbonate $\left(\mathrm{CaCO}_{3}\right)$ & $\left(\mathrm{g} \mathrm{kg}^{-1}\right)$ & 15 & 20 \\
Cation exchange capacity $(\mathrm{CEC})$ & $\left(\mathrm{cmol}_{\mathrm{c}} \mathrm{kg}^{-1}\right)$ & 26 & 25 \\
Total organic C (TOC) & $\left(\mathrm{g} \mathrm{kg}^{-1}\right)$ & 10.6 & 7.7 \\
Total Kjeldahl N (TKN) & $\left(\mathrm{g} \mathrm{kg}^{-1}\right)$ & 1.1 & 0.91 \\
C: N ratio & - & 10 & 8.5 \\
Olsen-P & $\left(\mathrm{mg} \mathrm{kg}^{-1}\right)$ & 18 & 42 \\
Total Mn & $\left(\mathrm{mg} \mathrm{kg}^{-1}\right)$ & 42 & 40 \\
Total Cr & $\left(\mathrm{mg} \mathrm{kg}^{-1}\right)$ & 25 & 23 \\
Extractable Cr & $\left(\mathrm{mg} \mathrm{kg}^{-1}\right)$ & 0.63 & 0.57 \\
Cr(VI) & $\left(\mathrm{mg} \mathrm{kg}^{-1}\right)$ & $<0.5^{*}$ & $<0.5 *$ \\
\hline * Detection liat. & & &
\end{tabular}

${ }^{*}$ Detection limit.

mainly depends on soil microbial processes of mineralization and immobilization whose turnover is mainly influenced by its $\mathrm{C}: \mathrm{N}$ ratio, although the soil $\mathrm{N}$ turnover cannot be explained by this parameter alone. Soil chemical-physical characteristics and biosolid properties such as soluble $\mathrm{C}$ content, $\mathrm{N}$ biochemical quality, and phenolic content could play a crucial role in determining $\mathrm{N}$ mineralization [1216]. Specific studies on the mineralization dynamic of the organic $\mathrm{N}$ in biosolids are therefore required in order to evaluate $\mathrm{N}$ supply to plants and to avoid leaching of $\mathrm{N}$ in the environment.

At present little is known about TLP-Cr(III) behaviour in soil and, in particular, on the dynamics of its extractable fraction, likely to be available to soil microorganisms.

The aim of this research was to study the effects of applying agronomical rates of TLP on (i) C and $\mathrm{N}$ mineralization, (ii) soil microbial biomass $\mathrm{N}$, (iii) protease activity, and (iv) extractable $\mathrm{Cr}$ (III) dynamics in two agricultural soils in a short-term laboratory experiment.

\section{Materials and Methods}

2.1. Chemical Characterization of Tannery Land Plaster. A chemical characterization of TLP was carried out (Table 1) to determine water and ash content, total (TS) and volatile solids (VS), $\mathrm{pH}$, electrical conductivity (EC), total organic carbon (TOC), and nitrogen (TN), ammonium $\left(\mathrm{NH}_{4}{ }^{+}-\mathrm{N}\right)$, nitrates $\left(\mathrm{NO}_{3}{ }^{-}-\mathrm{N}\right)$, water extractable hexavalent chromium $[\mathrm{Cr}(\mathrm{VI})]$, total nutrients, and the most representative trace heavy metal contents. Water content was determined after oven drying at $105^{\circ} \mathrm{C}$ for $24 \mathrm{~h}, \mathrm{pH}$ and $\mathrm{EC}$ were measured according to the method reported by Trinchera et al. [17]. TOC was determined by the $\mathrm{K}_{2} \mathrm{Cr}_{2} \mathrm{O}_{7}$ oxidation method described by Ciavatta et al. [18], TN using an elemental analyzer (Thermo Fisher Scientific) and mineral $\mathrm{N}$ according 
to the method reported by Violante [19]. Other nutrients and heavy metals were determined by inductively coupled plasma optical emission spectroscopy (ICP-OES, Spectro Ciros ${ }^{\mathrm{CCD}}$ ) after digestion of the sample with $65 \% \mathrm{HNO}_{3}$. The $\mathrm{Cr}(\mathrm{VI})$ was determined by 1,5-diphenylcarbazide colorimetric analysis after water extraction [17].

2.2. Soil Properties and Incubation Conditions. Two soils (Typic Udifluvent, USDA Soil Taxonomy) representative of an important agricultural area located in the southeast of the Po valley (Ravenna, Italy), hereinafter named $\mathrm{M}$ and $\mathrm{P}$, were chosen for the experiment because they are involved in a larger study, in which the TLP is used for the N fertilization of maize and tomato under field conditions (Table 2). Soil samples from the top layer $(0-20 \mathrm{~cm}$ depth) were collected in the early spring of 2007, wet-sieved at $4 \mathrm{~mm}$, and then air-dried. Chemical analyses were carried out using the official Italian methods [19]. Water holding capacity (WHC) was determined as described by Agehara and Warncke [20]. Total Cr was determined by ICP-OES after digestion with $65 \% \mathrm{HNO}_{3}$ while $\mathrm{Cr}(\mathrm{VI})$ in the water extract by diphenylcarbazide colorimetric method [21]. Extractable Cr was evaluated using the rhizosphere-based method [22]. Briefly, $2 \mathrm{~g}$ of moist soils were mixed with $20 \mathrm{~mL}$ of combined solution of acetic, lactic, citric, malic, and formic acids in a $50 \mathrm{~mL}$ centrifuge tube (extraction ratio $1: 10 \mathrm{w} / \mathrm{v}$ ). The concentration of the organic acids was $10 \mathrm{mM}$, and their molar ratio was $4: 2: 1: 1: 1$, respectively. The soil suspension was shaken by an end-over-end shaker for $16 \mathrm{~h}$ $(60 \mathrm{rpm})$, centrifuged at $1000 \mathrm{~g}$ for $10 \mathrm{~min}$ and filtered with Whatman no. 42 filter paper. Five $\mathrm{mL}$ of supernatant were mixed with $5 \mathrm{~mL}$ of $2 \% \mathrm{HNO}_{3}$. The $\mathrm{Cr}$ content in soil extracts was determined by ICP-OES.

The soils were preconditioned for 14 days at $70 \%$ of their WHC at $25^{\circ} \mathrm{C}$, to enable acclimatization to incubation conditions. At the end of this period, 3.16 and $6.32 \mathrm{mg} \mathrm{g}^{-1}$ dry soil of TLP (previously lyophilised and grounded) corresponding to 0.18 and $0.36 \mathrm{mg} \mathrm{N} \mathrm{g}^{-1}$ of dry soil, respectively, were added to $150 \mathrm{~g}$ soil samples. The application rates were calculated on an agronomic basis and corresponded to 220 and $440 \mathrm{~kg}$ of $\mathrm{N} \mathrm{ha}^{-1}$, respectively. Unamended soil was taken as the control. The experiment was carried out in triplicate and soils were sampled after $0,3,7,14,28$, and 56 days of incubation that was performed in the dark at the same conditions adopted in the pre-conditioning phase.

2.3. Extractable Mineral N. Aliquots of $5 \mathrm{~g}$ of soil samples were extracted with $50 \mathrm{~mL}$ of $0.5 \mathrm{M} \mathrm{K}_{2} \mathrm{SO}_{4}$ for 1 hour. Extractable $\mathrm{NH}_{4}{ }^{+}-\mathrm{N}$ and $\mathrm{NO}_{3}{ }^{-}-\mathrm{N}$ were determined by the Bran Luebbe AACE 5.46 Auto Analyzer method. The $\mathrm{NO}_{2}{ }^{-}$$\mathrm{N}$ content was assumed to be negligible in comparison with $\mathrm{NH}_{4}{ }^{+}-\mathrm{N}$ and $\mathrm{NO}_{3}{ }^{-}-\mathrm{N}$.

The cumulative amount of mineral $\mathrm{N}$ released from TLP at time $t\left(\mathrm{~N}_{\text {TLP }}\right)$ was calculated using the following equation:

$\mathrm{N}_{\mathrm{TLP}}=\mathrm{N}_{m}(\text { TLP-treated soil })_{t}-\mathrm{N}_{m}(\text { control })_{t}-\mathrm{N}_{m}$ TLP,

where $\mathrm{N}_{m}$ is the mineral $\mathrm{N}$ content $\left(\mathrm{NH}_{4}{ }^{+}-\mathrm{N}+\mathrm{NO}_{3}{ }^{-}-\mathrm{N}\right)$.
The percentage of organic $\mathrm{N}$ released from TLP at time $t$ $\left(\% \mathrm{~N}_{\mathrm{TLP}}\right)$ was calculated using the following equation:

$$
\% \mathrm{~N}_{\mathrm{TLP}}=\left(\frac{\mathrm{N}_{\mathrm{TLP}}}{\mathrm{N}_{0 \mathrm{TLP}}}\right) * 100 .
$$

$\mathrm{N}_{\text {OTLP }}$ is the amount of organic $\mathrm{N}$ in TLP sample calculated as follows: $\mathrm{N}_{0 T L P}=\mathrm{TN}_{\mathrm{TLP}}-\mathrm{MN}_{\mathrm{TLP}}$, where $\mathrm{TN}_{\mathrm{TLP}}$ is the total $\mathrm{N}$ in TLP samples and $\mathrm{MN}_{\mathrm{TLP}}$ is the mineral $\mathrm{N}$ in TLP sample.

The percentage of mineral $\mathrm{N}$ released was fitted to a firstorder model [21] using a nonlinear curve-fitting procedure:

$$
\% \mathrm{~N}_{\mathrm{TLP}}=\% \mathrm{~N}_{0} *\left[1-\exp \left(-\mathrm{k}_{0} * t\right)\right],
$$

where $\% \mathrm{~N}_{0}$ is the $\%$ of potentially mineralizable organic $\mathrm{N}$ added; $\mathrm{k}_{0}$ is the first-order rate constant $\left(\right.$ day $\left.^{-1}\right)$.

The $\mathrm{N}_{0}$ and $\mathrm{k}_{0}$ values were deemed significantly different $(\alpha=0.05)$ if the $95 \%$ confidence intervals did not overlap.

2.4. Biochemical Analysis. Ninhydrin (2,2-dihydroxyindane1,3-dione) reactive $\mathrm{N}$ content of the microbial biomass was determined on soil extracts obtained using the fumigation extraction method [23]. Moist soil portions, equivalent to $10 \mathrm{~g}$ of oven dried soil each, were fumigated with ethanol-free chloroform for $24 \mathrm{~h}$, then extracted with $40 \mathrm{~mL} 0.5 \mathrm{M} \mathrm{K}_{2} \mathrm{SO}_{4}$ for 30 minutes. Unfumigated soil samples were similarly extracted. Microbial biomass ninhydrin reactive $\mathrm{N}$ was calculated by the difference between the ninhydrin $\mathrm{N}$ value extracted by $\mathrm{K}_{2} \mathrm{SO}_{4}$ from fumigated samples subtracted with the ninhydrin $\mathrm{N}$ value extracted by $\mathrm{K}_{2} \mathrm{SO}_{4}$ from unfumigated samples [24].

Protease activity was determined according to Ladd and Butler [25]. Moist soil (1 $\mathrm{g}$ oven dry basis) was mixed with $5 \mathrm{~mL}$ TRIS (2-Amino-2-hydroxymethyl-propane-1,3diol) buffer ( $\mathrm{pH} 8.1$ ), and $5 \mathrm{~mL}$ of $2 \% \mathrm{Na}$-casein (suspended in the TRIS buffer). The soil mixture was incubated in a shaking water bath at $50^{\circ} \mathrm{C}$ for $2 \mathrm{~h}$. Controls were performed by adding the substrate suspension after the incubation. The reaction was stopped with $5 \mathrm{~mL}$ of $15 \%$ trichloroacetic acid solution (TCA) and the suspension was centrifuged for $10 \mathrm{~min}$ at $5000 \mathrm{rpm}$. The clear supernatant $(5 \mathrm{~mL})$ was placed in tubes, treated with $7.5 \mathrm{~mL}$ of a $50: 1: 1$ mixture of $0.06 \mathrm{M}$ $\mathrm{NaOH}, 5 \% \mathrm{Na}_{2} \mathrm{CO}_{3} 0.5 \%, \mathrm{CuSO}_{4} \cdot 5 \mathrm{H}_{2} \mathrm{O}$, and $1 \%$ potassium sodium tartrate and incubated for 15 minutes. After the incubation, $5 \mathrm{~mL}$ of $33 \%$ Folin-Ciocalteu reagent (FCR) were added and after $1 \mathrm{~h}$, the absorbance was determined at $\lambda$ $700 \mathrm{~nm}$.

Microbial respiration was measured using the method described by Isermeyer [26]. $\mathrm{CO}_{2}$ evolution was measured after $1,2,3,5,7,9,14$, and 21 days on aliquots of moist soils ( $10 \mathrm{~g}$ oven dry basis; $70 \% \mathrm{WHC}$ ) incubated at $25^{\circ} \mathrm{C}$ in glass jars by means of $10 \mathrm{~mL} 1 \mathrm{M} \mathrm{NaOH}$ traps. Three replicates were carried out as well as blank $\mathrm{CO}_{2}$ traps without soil samples. $\mathrm{CO}_{2}$ evolution was determined by adding $2 \mathrm{~mL}$ of $0.5 \mathrm{M} \mathrm{BaCl}_{2}$ to $\mathrm{CO}_{2}$ traps and titrating to $8.8 \mathrm{pH}$ with $0.025 \mathrm{M} \mathrm{HCl}$. The respiration rate $\left(\mu \mathrm{g} \mathrm{CO}_{2}-\mathrm{Cg}^{-1}\right.$ soil h$\left.{ }^{-1}\right)$ and the cumulative evolved $\mathrm{CO}_{2}\left(\mu \mathrm{g} \mathrm{CO} \mathrm{CO}_{2}-\mathrm{Cg}^{-1}\right.$ soil $)$ were calculated. 


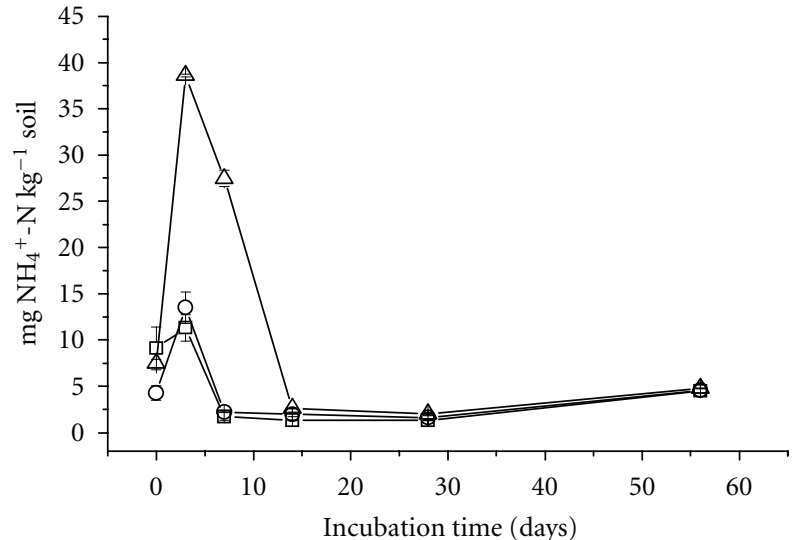

(a)

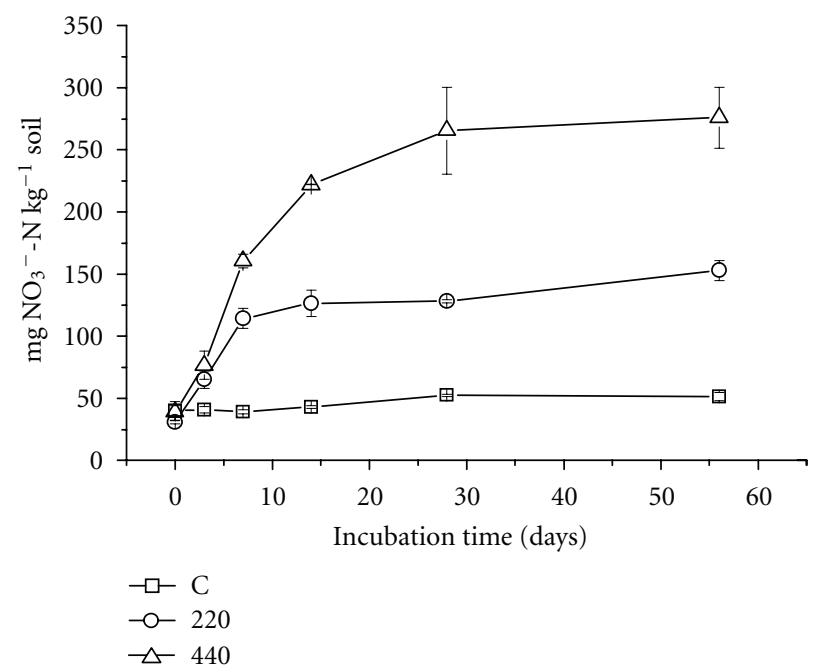

(c)

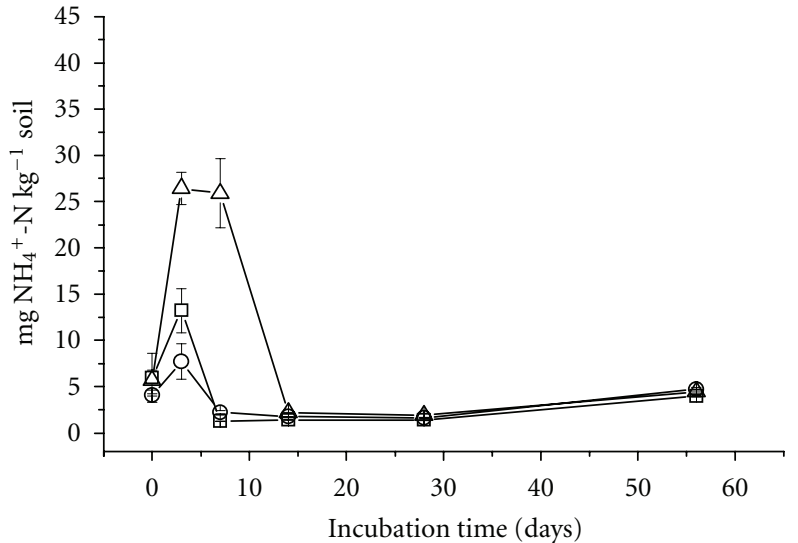

(b)

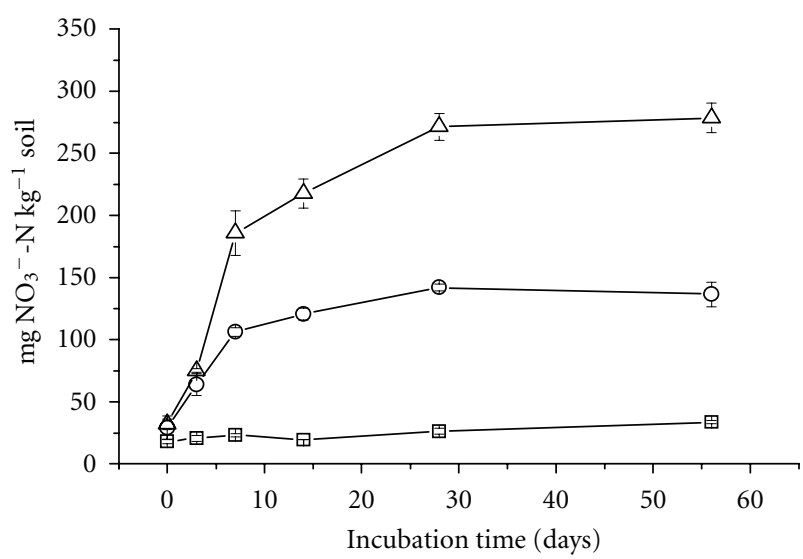

$\rightarrow \square-C$

$-\infty 220$

$\triangle 440$

(d)

FIGURE 1: Concentrations of $\mathrm{K}_{2} \mathrm{SO}_{4}$ extractable $\mathrm{NH}_{4}{ }^{+}-\mathrm{N}$ in soil $\mathrm{M}$ (a) and soil $\mathrm{P}$ (b) and $\mathrm{K}_{2} \mathrm{SO}_{4}$ extractable $\mathrm{NO}_{3}{ }^{-}-\mathrm{N}$ in soil M (c) and soil $\mathrm{P}$

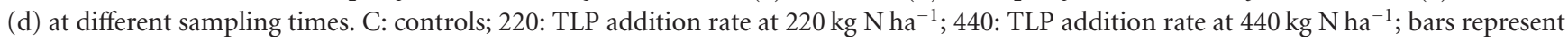
standard deviation $(n=3)$.

2.5. Data Analysis. An overall analysis of variance (ANOVA) was used for each dependent variable; the model included the main effects of soil type and amendment and their two-way interaction.

Data obtained at each sampling time and from each soil type were subjected to one-way analysis of variance and to mean separation by Bonferroni test at $* P \leq 0.05$ significant levels.

\section{Results and Discussion}

3.1. Pattern of Mineral-N Release. The mineralization process started immediately after TLP addition and a significant accumulation of $\mathrm{NH}_{4}{ }^{+}-\mathrm{N}$ was observed in both soils treated with $440 \mathrm{~kg} \mathrm{Nha}{ }^{-1}$ during the first week of incubation (Figure 1). The concentration of $\mathrm{NH}_{4}{ }^{+}-\mathrm{N}$ then rapidly decreased and from the 2 nd week of incubation was very similar to the other treatments. On the contrary, both soils treated with $220 \mathrm{~kg} \mathrm{Nha}^{-1}$ showed values of extractable $\mathrm{NH}_{4}{ }^{+}-\mathrm{N}$ similar to the controls.

Amendment with TLP caused a significant increase of $\mathrm{NO}_{3}{ }^{-}-\mathrm{N}$ in both soils (Figure 1), detectable from the 3rd day of incubation. After a week, a significant effect of the application rate was detected in both soils and at the end of incubation the $\mathrm{NO}_{3}{ }^{-}-\mathrm{N}$ concentration a stabilization was shown.

The percentages of net cumulative mineral $\mathrm{N}\left(\mathrm{NH}_{4}{ }^{+}-\mathrm{N}\right.$ $\left.+\mathrm{NO}_{3}{ }^{-}-\mathrm{N}\right)$, fitted to a first kinetic order model, are reported in Figure 2. After 14 days of incubation, from 45 to 55\% of the $\mathrm{N}$ added with TLP was mineralized and the values reached 57 to $68 \%$ at the end of the experiment.

The organic $\mathrm{N}$ added with TLP was readily mineralized to $\mathrm{N}-\mathrm{NH}_{4}{ }^{+}$and further converted into $\mathrm{N}-\mathrm{NO}_{3}{ }^{-}$, regardless of the soil type and the addition rate. The extent and dynamics of $\mathrm{N}$ mineralization observed in this study are in agreement with other results obtained with different organic fertilizers 


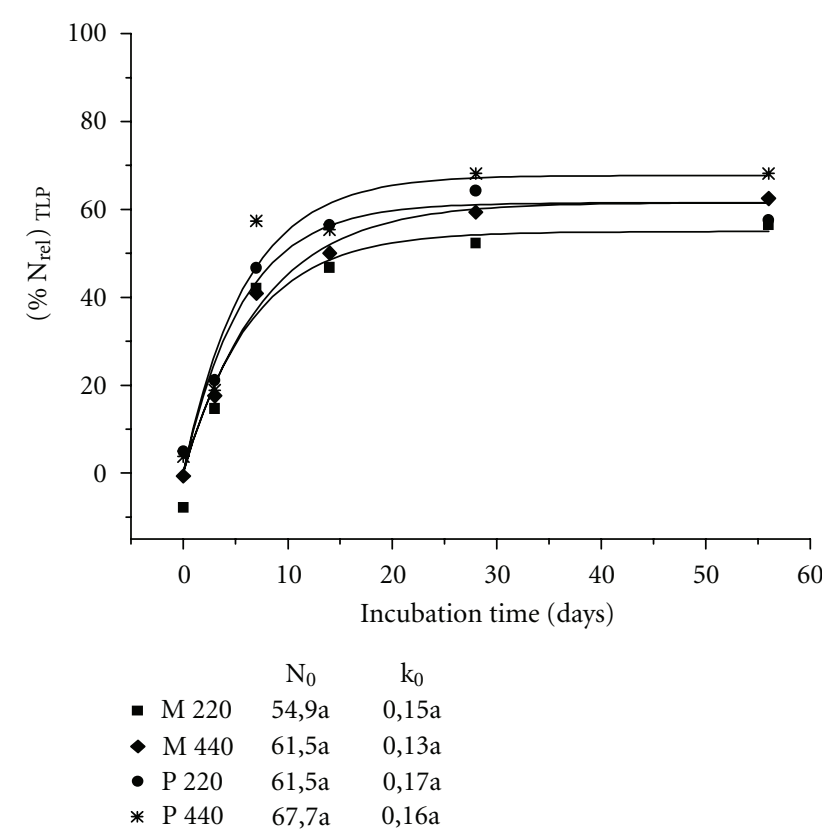

Figure 2: Percentage of the net cumulative $\mathrm{N}$ released by TLP into $\mathrm{M}$ and $\mathrm{P}$ soils. The $\mathrm{N}_{0}$ or $\mathrm{k}_{0}$ values followed by the same letter are not significantly different at $\alpha=0.05$.

such as meat and bone meal [27], and with blood meal [21]. It is generally accepted that the main factors affecting $\mathrm{N}$ mineralization in soil treated with organic materials are the $\mathrm{C}: \mathrm{N}$ ratio and the biochemical quality and $\mathrm{N}$ content $[15,28]$.

3.2. Biochemical Properties. Dynamics of $\mathrm{C}$ mineralization, measured as $\mathrm{CO}_{2}-\mathrm{C}$ evolution rate, were characterized by a peak occurring after 3 days of incubation, followed by a progressive decrease (Figure 3). The amount of evolved $\mathrm{CO}_{2}-\mathrm{C}$ was clearly affected by the application rate; soils treated with larger amounts of TLP were characterized by a significantly higher rate of $\mathrm{CO}_{2}-\mathrm{C}$ evolution versus the soils treated with the lowest amount of TLP. On the contrary, the soil type did not affect the $\mathrm{CO}_{2}-\mathrm{C}$ evolution rate (Table 3 ).

In both soils and for both rates of application, TLP induced a significant increase in $B_{\text {NIN }}$ versus the control soils, 3-7 days after the amendment (Figure 4). However, the turnover of the microbial biomass $\mathrm{N}$ in soils treated with TLP was quite rapid with a tendency to decrease towards values approaching the controls by the end of the incubation. The ANOVA showed a significant influence of both the soil type and the amendment, but did not detect a significant effect of the TLP application rate (Table 3 ).

Protease activity (Figure 4) showed a marked increase with a maximum occurring 7-14 days after the TLP addition; in soil $\mathrm{P}$ the increase was faster than in soil $\mathrm{M}$. The protease activity of treated soils remained significantly higher than the controls until the end of the incubation period, and the ANOVA revealed a significant effect of both the soil type and the TLP application rates (Table 3 ).

Dilly and Nannipieri [29] reported that the increase in soil respiration, enzyme activities, and microbial biomass

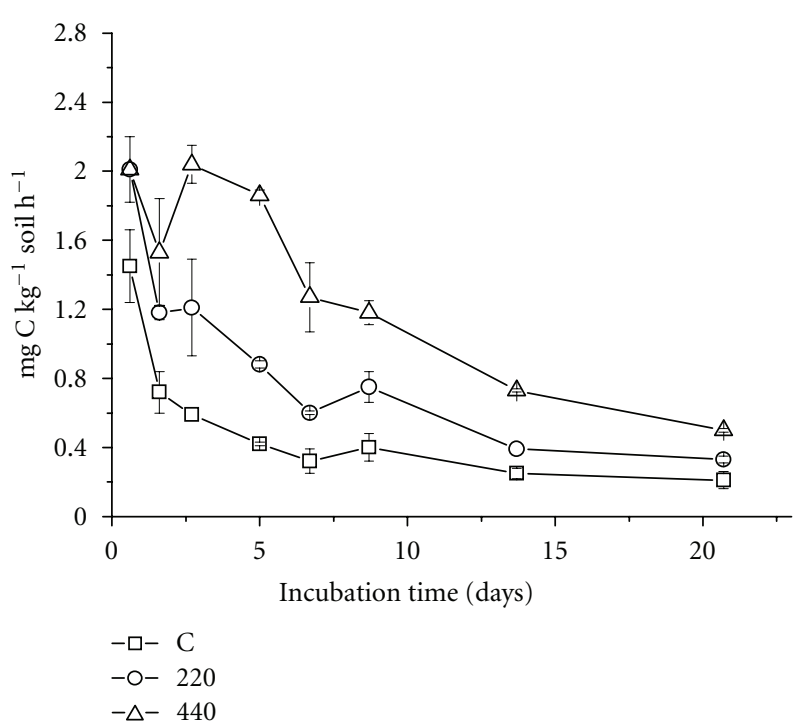

(a)

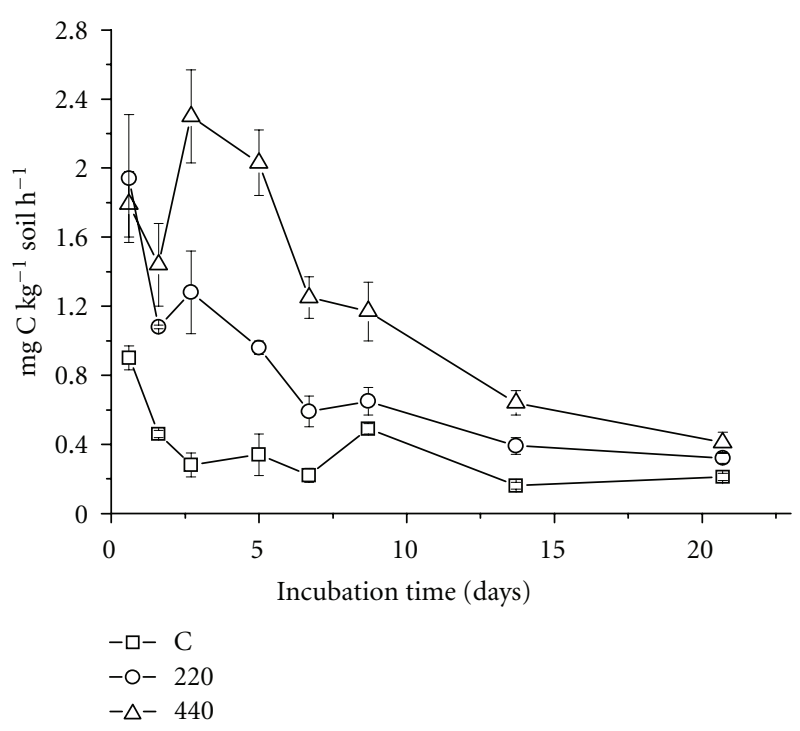

(b)

Figure 3: Dynamics of $\mathrm{CO}_{2}$-C evolution rate in soil $\mathrm{M}$ (a) and soil $\mathrm{P}$ (b) at different sampling time. C: controls; 220: TLP addition rate at $220 \mathrm{~kg} \mathrm{~N} \mathrm{ha}^{-1}$; 440: TLP addition rate at $440 \mathrm{~kg} \mathrm{~N} \mathrm{ha}^{-1}$; bars represent standard deviation $(n=3)$.

after the addition of easily decomposable substrates to the soil are clear indicators of an increased microbial activity. In our experiment, these parameters were positively influenced by the TLP addition, pointing out to the absence of a significant action of potentially toxic or detrimental substances that could hamper microbial growth or activities. Dynamics of $\mathrm{CO}_{2}-\mathrm{C}$ evolution showed that TLP addition caused an increase in soil respiration rate, indicating the presence of readily available substances that soil microorganisms can use as sources of $\mathrm{C}$ and energy. The extra cumulative $\mathrm{CO}_{2}-\mathrm{C}$ that evolved after 21 days of incubation with TLP $(23-32 \%$ of the added C) was higher with respect to the values recorded with other substrates of animal origin, such as meat and 
TABLE 3: Results of the F-test from an overall ANOVA for extractable $\mathrm{NH}_{4}{ }^{+}-\mathrm{N}$, extractable $\mathrm{NO}_{3}{ }^{-}-\mathrm{N}$, protease activity, respiration rate, microbial biomass, and extractable $\mathrm{Cr}$.

\begin{tabular}{lccccc}
\hline Parameter & Soil & Control versus 220 & $\begin{array}{c}\text { Fertilization rate } \\
\text { Control versus 440 }\end{array}$ & 220 versus 440 & Soil type fertilization rate \\
\hline Extractable $\mathrm{NH}_{4}{ }^{+}-\mathrm{N}$ & $\mathrm{ns}$ & $\mathrm{ns}$ & $<0.05$ & $<0.05$ & $\mathrm{~ns}$ \\
Extractable $\mathrm{NO}_{3}{ }^{-}-\mathrm{N}$ & $\mathrm{ns}$ & $<0.05$ & $<0.05$ & $<0.05$ & $\mathrm{~ns}$ \\
Protease activity & $<0.05$ & $<0.05$ & $<0.05$ & $<0.05$ & $\mathrm{~ns}$ \\
Respiration rate & $\mathrm{ns}$ & $<0.05$ & $<0.05$ & $<0.05$ & $\mathrm{~ns}$ \\
Microbial biomass & $<0.05$ & $<0.05$ & $<0.05$ & $\mathrm{~ns}$ & $\mathrm{~ns}$ \\
Extractable Cr & $\mathrm{ns}$ & $<0.05$ & $<0.05$ & $<0.05$ & $\mathrm{~ns}$ \\
\hline
\end{tabular}

${ }^{*}$ ns: not significant at $P>0.05$.

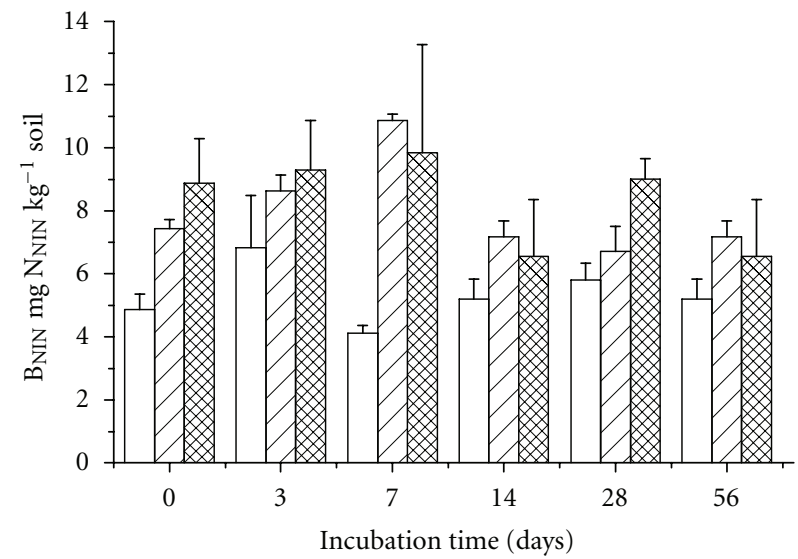

(a)
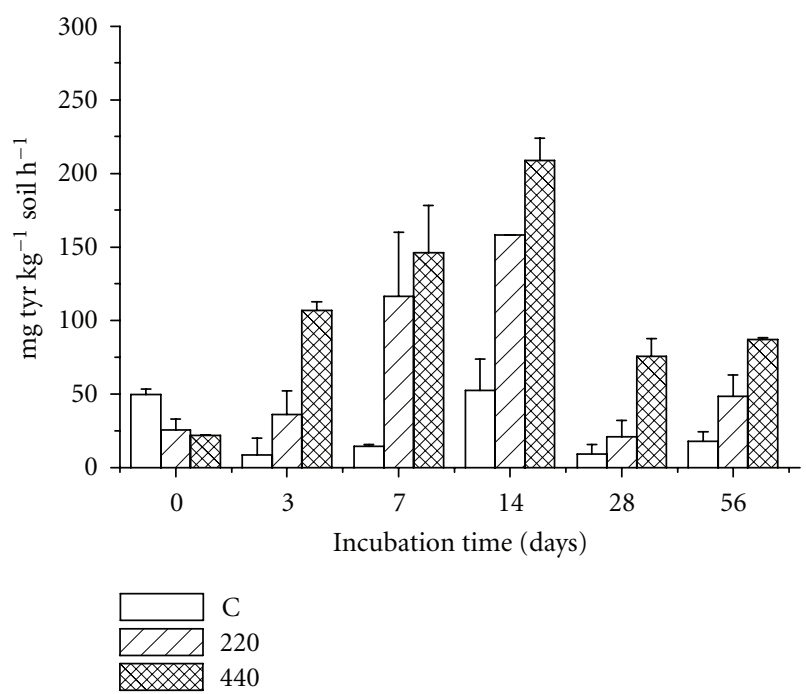

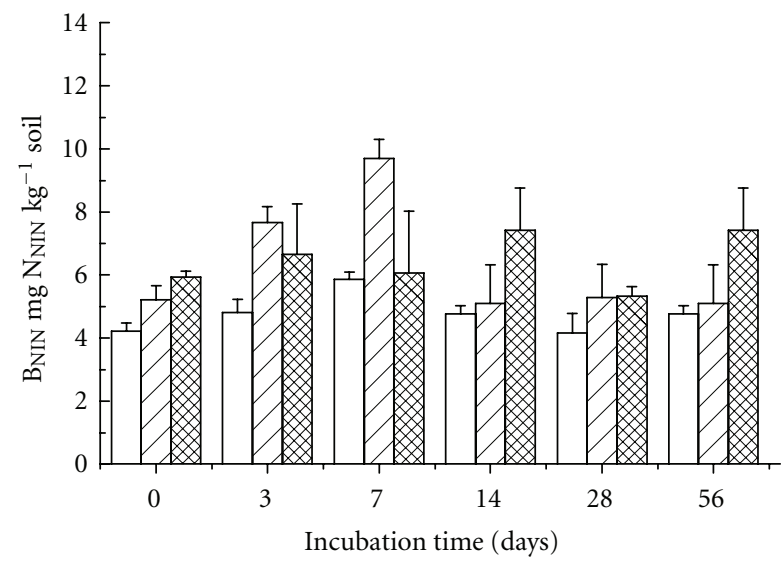

(b)

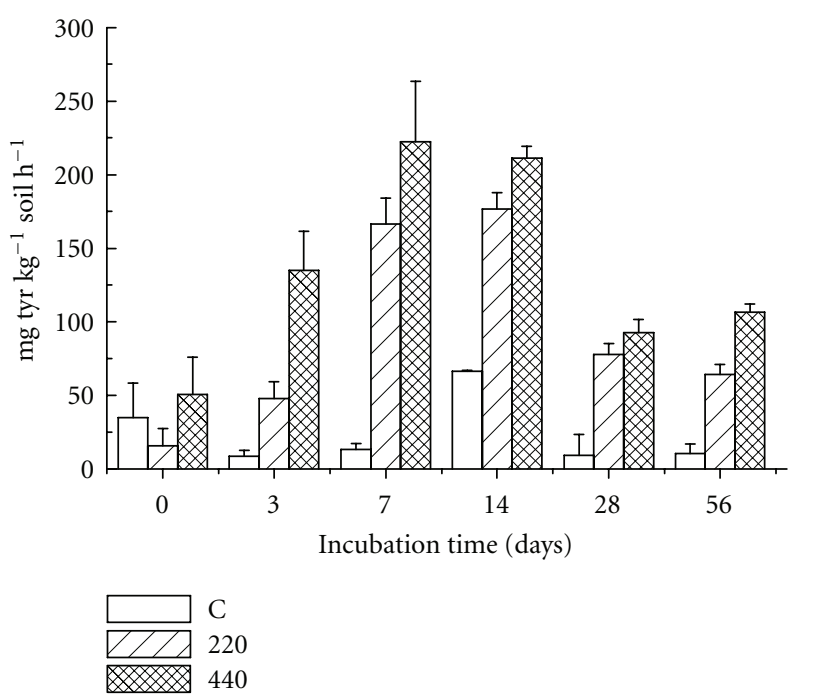

(d)

Figure 4: Microbial biomass ninhydrin-reactive $\mathrm{N}\left(\mathrm{B}_{\mathrm{NIN}}\right)$, in soil $\mathrm{M}(\mathrm{a})$ and soil $\mathrm{P}(\mathrm{b})$ and protease activity in soil $\mathrm{M}$ (c) and soil $\mathrm{P}$ (d) at different sampling time. C: controls; P. 220: TLP addition rate at $220 \mathrm{~kg} \mathrm{~N}^{-1}$; 440: TLP addition rate at $440 \mathrm{~kg} \mathrm{~N}^{-1}$; bars represent standard deviation $(n=3)$.

bone meal (10-16\%) [27], poultry manure, and pig slurry (16 and 19\% resp.) [30]. This could be due to differences in the microbial use efficiency of the added $\mathrm{C}$ and could have caused the limited and transitory increase of microbial biomass shown by the $\mathrm{B}_{\mathrm{NIN}}$ parameter.
Soil extracellular proteases are produced by a wide range of bacteria, especially actinomycetes, and fungi, are stimulated by the addition of organic residues containing $\mathrm{N}$ in proteinaceous forms through mechanisms of substrate induction and are positively correlated with the amount 
of added substrates [31]. On the other hand, when high levels of end products such as amino acids, $\mathrm{NH}_{4}{ }^{+}-\mathrm{N}$ and easily available $\mathrm{C}$ sources are abundant, the allocation of resources to protease production may be repressed. However, a fraction of soil proteases can be stabilized by interaction with the soil matrix and may be insensitive to environmental conditions that affect microbes. TLP addition caused a marked increase in protease activity and this increase was positively influenced by the TLP addition rate. The presence of end products apparently did not repress proteases. During the rapid phase of organic $\mathrm{N}$ mineralization, the lack of evident protease repression could be due to the fact that substrate induction was the dominant mechanism regulating enzyme synthesis and release and dwarfed the repression mechanisms caused by directly available $\mathrm{C}$ and $\mathrm{N}$ sources [31]. After 8 weeks of incubation, the levels of protease activity in the amended samples remained relatively constant and significantly higher than the controls. We hypothesize that stabilization processes of extracellular protease had occurred $[27,29]$, preventing the enzymatic activity from falling below basal levels [32].

The dynamics of $\mathrm{CO}_{2}-\mathrm{C}$ evolution, $\mathrm{B}_{\mathrm{NIN}}$ and protease activity suggest a tendency of soils microorganisms to use the substrate to produce energy, with a reduced ability to promote a stable microbial growth. The energy obtained by the intense processes of $\mathrm{C}$ and $\mathrm{N}$ mineralization could have been used to sustain the intense enzymatic synthesis observed in the treated soils.

3.3. Chromium Oxidation and Extractable Fraction. The high concentration of $\mathrm{Cr}$ (III) in TLP is a matter of great concern for its agronomical use. As known, $\mathrm{Cr}$ (III) is characterized by a scarce mobility in both soil and plants, and generally only a small fraction of the $\mathrm{Cr}$ in soil is available to plants and microorganisms $[6,33]$. On the contrary, $\mathrm{Cr}(\mathrm{VI})$ shows high mobility in soils and toxicity to plants and animals. In order to exclude the oxidation of $\mathrm{Cr}$ (III) to $\mathrm{Cr}(\mathrm{VI})$ in soil, the determination of water extractable $\mathrm{Cr}(\mathrm{VI})$ was carried out at each sampling time: $\mathrm{Cr}(\mathrm{VI})$ was never detected throughout the incubation experiment (data not shown).

Since the extent of the extractable fraction is the main element determining the effect of $\mathrm{Cr}$ on microorganisms and plants, we monitored its dynamics during the TLP mineralization. Figure 5 shows the dynamics of the extractable $\mathrm{Cr}$ fraction, using the extraction method described by Feng et al. [22]. At the beginning of the incubation period from 12.6 to $16 \%$ of the total $\mathrm{Cr}$ added to the soil with TLP was extractable by the organic acid solution. After 3 days of incubation, the percentage of extractable $\mathrm{Cr}$ decreased to $50 \%$, regardless of the soil type and the TLP addition rate. The extractable $\mathrm{Cr}$ fraction then steadily decreased and at the end of the incubation period from 3.9 to $4.3 \%$ of the total $\mathrm{Cr}$ added was still extractable, although it was not influenced either by the soil type or TLP application rate (Table 3 ). The values of the controls were significantly lower (Table 2) and stable during the incubation period.

The extractable $\mathrm{Cr}$ fraction was clearly reduced during the period of incubation. This could be due to the precipita-

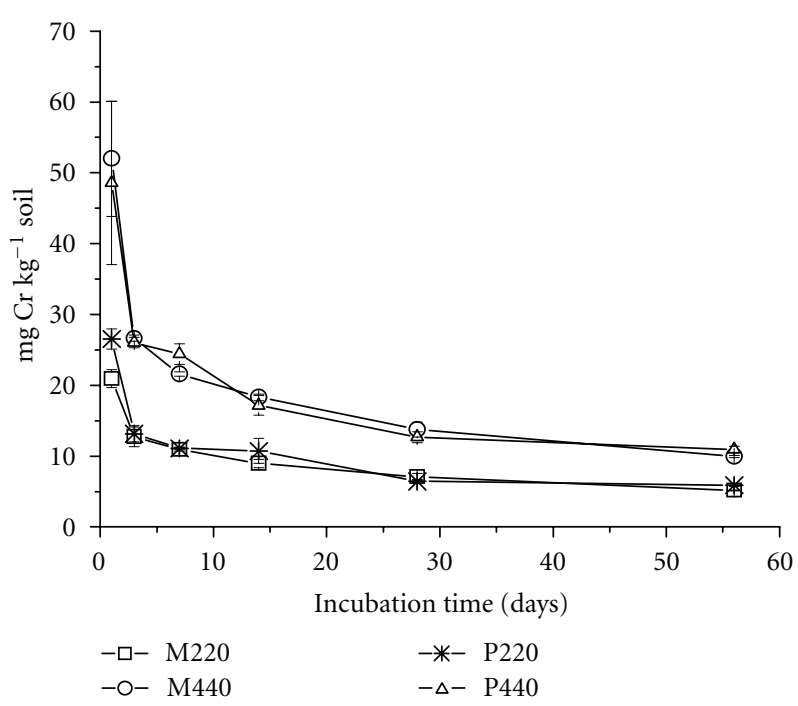

Figure 5: Dynamics of extractable $\mathrm{Cr}$ in soils $\mathrm{M}$ and P. 220: TLP addition rate at $220 \mathrm{~kg} \mathrm{Nha}^{-1}$; 440: TLP addition rate at $440 \mathrm{~kg}$ $\mathrm{N} \mathrm{ha}^{-1}$; bars represent standard deviation $(n=3)$.

tion of $\mathrm{Cr}$ (III) in insoluble forms (e.g., oxide and hydroxide $\mathrm{Cr}$ forms) in these alkaline soils relatively rich in carbonates [34].

\section{Conclusions}

TLP added to the soil was characterized by a fast mineralization. The net potential mineralization accounted for more than $50 \%$ of the added TLP-N during the first two weeks of incubation, indicating that TLP is a good source of readily available N. The addition of TLP caused a significant increase in the size and activity of microbial biomass, showed by soil respiration, $\mathrm{N}$ microbial biomass and protease. The increase of these parameters indicates no toxic or detrimental substance that could hamper microbial growth or inhibit microbial activity like protease at least in the short-term period. The extractable $\mathrm{Cr}$ (III) fraction was quickly reduced during the incubation and was probably involved in an intense precipitation process. Assuming that the rate of $\mathrm{N}$ mineralization and the effect on biological and microbiological soil properties represent some of the most important factors that we have to consider in the evaluation of the agronomical value of biosolids of industrial origin, we can conclude that TLP should be recycled in agriculture. However, the effect of repeated applications of TLP should be tested in order to evaluate the possibility of long-term accumulation of $\mathrm{Cr}$ in soil and its effect on biochemical parameters, in order to confirm the results obtained here.

\section{Acknowledgments}

The authers are grateful to S.I.C.IT. 2000 S.p.A. (Arzignano, Vicenza, Italy) for providing TLP product and to Dr. Andrea Simoni for his analytical support. 


\section{References}

[1] C. E. Clapp, M. H. B. Hayes, and C. Ciavatta, "Organic wastes in soils: biogeochemical and environmental aspects," Soil Biology and Biochemistry, vol. 39, no. 6, pp. 1239-1243, 2007.

[2] "Council Directive 99/31/EC of 26 April 1999 on the landfill of waste," Official Journal, L182, pp. 1-19, 1999.

[3] "Directive 2000/76/EC of the European parliament and Council of 4 December 2000 on the incineration of waste," Official Journal, L145, 2000.

[4] M. Loizidou, D. Malamis, S. Malamis, G. Xydis, and K. Moustakas, "Assessment of the existing situation and the related legislation in EU in connection with sludge management," MOROCOMP LIFE TCY05/MA000141, pp. 30-81, 2006.

[5] "Council Directive 86/278/CEE of 12 June 1986 on the protection of the environment, and in particular of the soil, when sewage sludge is used in agriculture," Official Journal, L181, 1986.

[6] A. M. Zayed and N. Terry, "Chromium in the environment: factors affecting biological remediation," Plant and Soil, vol. 249, no. 1, pp. 139-156, 2003.

[7] S. Canali, F. Tittarelli, and P. Sequi, Eds., Chromium Environmental Issues, FrancoAngeli, Milano, Italy, 1997.

[8] C. Cervantes, J. Campos-Garcia, S. Devars, F. GutiérrezCorona, H. Loza-Tavera, and J. C. Torres Guzman, "Interaction of chromium with micro organisms and plants," FEMS Microbiology Reviews, vol. 2, pp. 335-347, 2001.

[9] C. N. Liang and M. A. Tabatabai, "Effects of trace elements on nitrogen mineralisation in soils," Environmental Pollution, vol. 12, no. 2, pp. 141-147, 1977.

[10] P. C. Brookes, "The use of microbial parameters in monitoring soil pollution by heavy metals," Biology and Fertility of Soils, vol. 19, no. 4, pp. 269-279, 1995.

[11] E. Kandeler, C. Kampichler, and O. Horak, "Influence of heavy metals on the functional diversity of soil microbial communities," Biology and Fertility of Soils, vol. 23, no. 3, pp. 299-306, 1996.

[12] A. B. Joshi, D. R. Vann, and A. H. Johnson, "Litter quality and climate decouple nitrogen mineralization and productivity in Chilean temperate rainforests," Soil Science Society of America Journal, vol. 70, no. 1, pp. 153-162, 2006.

[13] P. Gioacchini, N. A. Ramieri, D. Montecchio, C. Marzadori, and C. Ciavatta, "Dynamics of mineral nitrogen in soils treated with slow-release fertilizers," Communications in Soil Science and Plant Analysis, vol. 37, no. 1-2, pp. 1-12, 2006.

[14] P. Gioacchini, L. M. Manici, N. A. Ramieri, C. Marzadori, and C. Ciavatta, "Nitrogen dynamics and microbial response in soil amended with either olive pulp or its by-products after biogas production," Biology and Fertility of Soils, vol. 43, no. 6, pp. 621-630, 2007.

[15] S. Sall, I. Bertrand, J. L. Chotte, and S. Recous, "Separate effects of the biochemical quality and $\mathrm{N}$ content of crop residues on C and N dynamics in soil," Biology and Fertility of Soils, vol. 43, no. 6, pp. 797-804, 2007.

[16] P. Roberts, R. Stockdale, M. Khalid, Z. Iqbal, and D. L. Jones, "Carbon-to-nitrogen ratio is a poor predictor of low molecular weight organic nitrogen mineralization in soil," Soil Biology and Biochemistry, vol. 41, no. 8, pp. 1750-1752, 2009.

[17] A. Trinchera, L. Leita, and P. Sequi, Metodi di analisi per i fertilizzanti, Ministero delle Politiche Agricole e ForestaliOsservatorio Nazionale Podologico e per la Qualità del Suolo Agricolo e Forestale, Delta Grafico, Città di Castello, Perugina, 2006.
[18] C. Ciavatta, L. Vittori Antisari, and P. Sequi, "Determination of organic carbon in soils and fertilizers," Communications in Soil Science \& Plant Analysis, vol. 20, no. 7-8, pp. 759-773, 1989.

[19] P. Violante, Metodi di analisi di chimica del suolo, MiPAF, Franco Angeli, Milano, Italy, 2000.

[20] S. Agehara and D. D. Warncke, "Soil moisture and temperature effects on nitrogen release from organic nitrogen sources," Soil Science Society of America Journal, vol. 69, no. 6, pp. 18441855, 2005.

[21] C. Ciavatta, D. Montecchio, and P. Sequi, "Applicazione di un test rapido per la determinazione del potere ossidante del terreno nei confronti del cromo," Acqua e Aria, vol. 9, pp. 875879, 1992.

[22] M.-H. Feng, X.-Q. Shan, S. Zhang, and B. Wen, "A comparison of the rhizosphere-based method with DTPA, EDTA, $\mathrm{CaCl}_{2}$, and $\mathrm{NaNO}_{3}$ extraction methods for prediction of bioavailability of metals in soil to barley," Environmental Pollution, vol. 137, no. 2, pp. 231-240, 2005.

[23] P. C. Brookes, A. Landman, G. Pruden, and D. S. Jenkinson, "Chloroform fumigation and the release of soil nitrogen: a rapid direct extraction method to measure microbial biomass nitrogen in soil," Soil Biology and Biochemistry, vol. 17, no. 6, pp. 837-842, 1985.

[24] R. G. Joergensen and P. C. Brookes, "Ninhydrin-reactive nitrogen measurements of microbial biomass in $0.5 \mathrm{M} \mathrm{K}_{2} \mathrm{SO}_{4}$ soil extracts," Soil Biology and Biochemistry, vol. 22, no. 8, pp. 1023-1027, 1990.

[25] J. N. Ladd and J. H. A. Butler, "Short-term assays of soil proteolytic enzyme activities using proteins and dipeptide derivatives as substrates," Soil Biology and Biochemistry, vol. 4, no. 1, pp. 19-30, 1972.

[26] H. Isermeyer, "Eine einfache Methode zur Bestimmung der Bodenatmung und der Carbonate," Pflanzenernah Bodenk, vol. 56, pp. 26-38, 1952.

[27] C. Mondini, M. L. Cayuela, T. Sinicco, M. A. SánchezMonedero, E. Bertolone, and L. Bardi, "Soil application of meat and bone meal. Short-term effects on mineralization dynamics and soil biochemical and microbiological properties," Soil Biology and Biochemistry, vol. 40, no. 2, pp. 462-474, 2008.

[28] M. Tejada, J. L. Gonzalez, A. M. García-Martínez, and J. Parrado, "Effects of different green manures on soil biological properties and maize yield," Bioresource Technology, vol. 99, no. 6, pp. 1758-1767, 2008.

[29] O. Dilly and P. Nannipieri, "Response of ATP content, respiration rate and enzyme activities in an arable and a forest soil to nutrient additions," Biology and Fertility of Soils, vol. 34, no. 1, pp. 64-72, 2001.

[30] R. Levi-Minzi, R. Riffaldi, and A. Saviozzi, "Carbon mineralization in soil amended with different organic materials," Agriculture, Ecosystems and Environment, vol. 31, no. 4, pp. 325-335, 1990.

[31] D. Geisseler and W. R. Horwath, "Regulation of extracellular protease activity in soil in response to different sources and concentrations of nitrogen and carbon," Soil Biology and Biochemistry, vol. 40, no. 12, pp. 3040-3048, 2008.

[32] S. D. Allison and P. M. Vitousek, "Responses of extracellular enzymes to simple and complex nutrient inputs," Soil Biology and Biochemistry, vol. 37, no. 5, pp. 937-944, 2005.

[33] S. Mishra, K. Shanker, M. M. Srivastava et al., "A study on the uptake of trivalent and hexavalent chromium by paddy (Oryza sativa): possible chemical modifications in 
rhizosphere," Agriculture, Ecosystems and Environment, vol. 62, no. 1, pp. 53-58, 1997.

[34] C. Ciavatta and P. Sequi, "Evaluation of chromium release during the decomposition of leather meal fertilizers applied to the soil," Fertilizer Research, vol. 19, no. 1, pp. 7-11, 1989. 

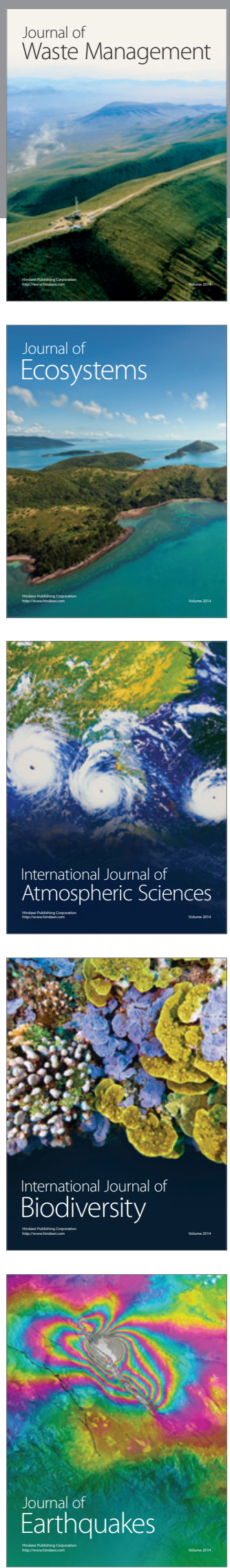
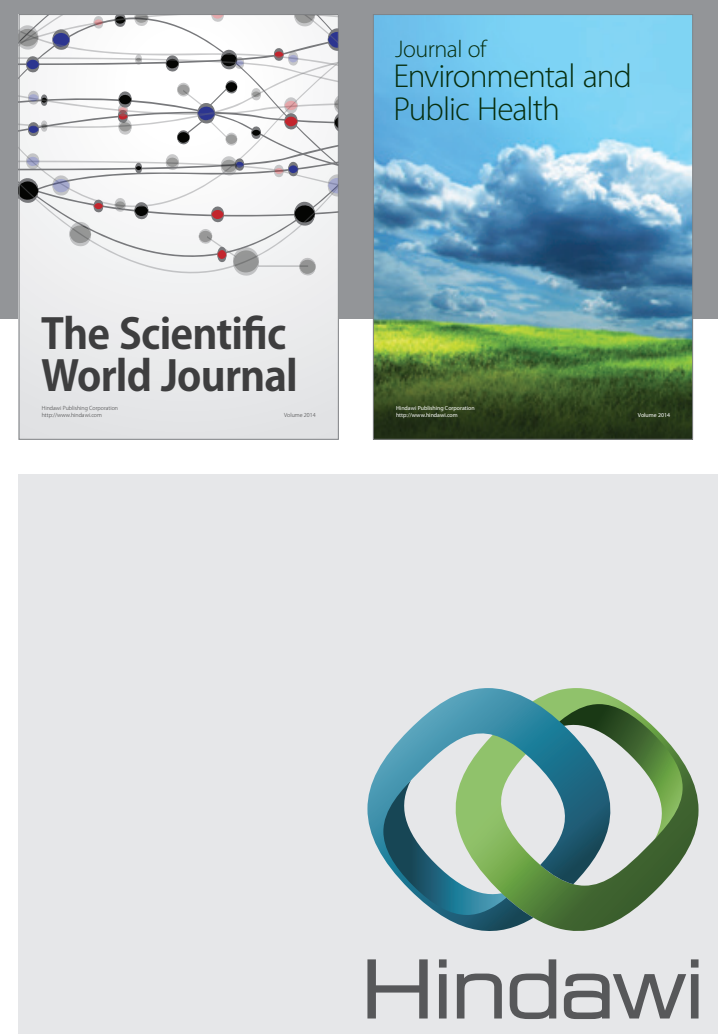

Submit your manuscripts at

http://www.hindawi.com
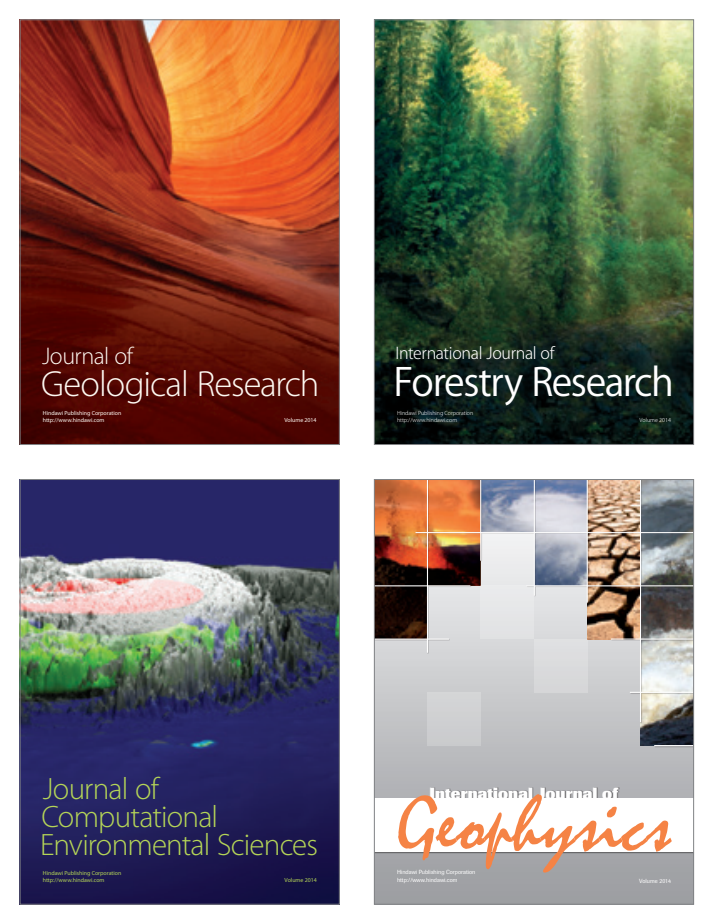
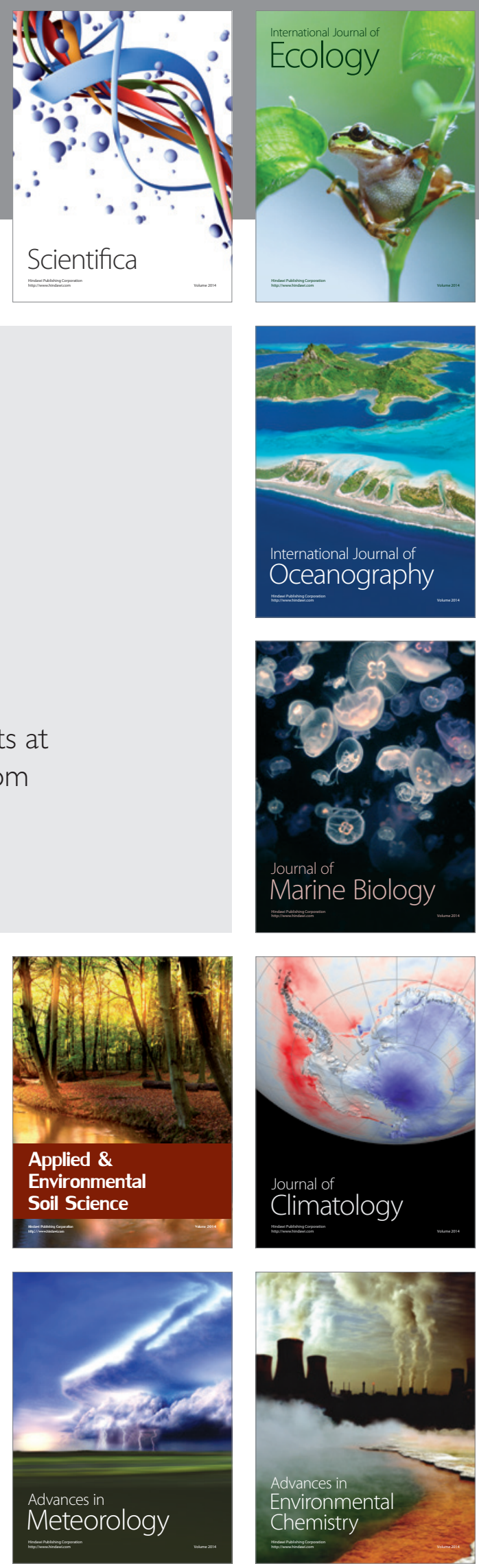